\title{
The Financial Performance on Asset Quality of Insurance Industry in Egypt (Panel Data Analysis)
}

\author{
Salah Mohamed Eladly ${ }^{1}$ \\ ${ }^{1}$ Lecturer of Finance, Higher Institute of Advanced Studies, Giza, Egypt \\ Correspondence: Salah Mohamed Eladly, Lecturer of Finance, Higher Institute of Advanced Studies, Giza, \\ Egypt.
}

Received: March 29, 2021

Accepted: April 19, 2021

Online Published: May 12, 2021

doi:10.5539/ibr.v14n6p24

URL: https://doi.org/10.5539/ibr.v14n6p24

\begin{abstract}
This study is an attempt to analyze the impact of the financial performance on asset quality of insurance industry in Egypt as applied on a sample of 19 insurance companies over the period 1999-2019.The financial performance measured by profitability (return on equity-return on investment) and liquidity results show that there is a significant negative linear relationship between the independent variable in terms of $\mathrm{X}_{3}$, and the dependent variable; $\mathrm{y}$, at a significant level less than (0.01), while there is no significant linear relationship between the independent variable of $X_{1}, X_{2}$, and dependent variable; $y$ at a significant level greater than (0.05) . The study methodology used panel data analysis according to ARDL model and OLS, beside the robustness check supports these results using the Jarque-Bera test and the Durbin-Watson test statistic
\end{abstract}

Keywords: profitability, liquidity, Asset quality, panel data analysis

\section{Introduction}

\subsection{Liquidity Constraints}

X3, Article (28) of the Egyptian Law (10) for the year 1981identifies how to allocate and invest funds:

1. At least $25 \%$ to purchase government securities, and secure certificates.

2. $10 \%$ of the paid capital to buy shares

3. $10 \%$ of the paid capital to buy bonds

4. $10 \%$ of the paid capital to invest in Real Estate

5. $10 \%$ of the paid capital to grants differences to guarantee commercial mortgages

6. $50 \%$ of the paid capital mostly cash

7. $10 \%$ of the paid capital mostly other investment approved by the regulator

\section{Literature Review}

David Byrne and Robert (2019), the result shows that the asset quality has a significant negative effect on impairment ratio through using pass-through, the gap between the non-performing loans and impairment ratio is significant, and grows relationship with the level of non-performing loans.

Rakesh Arrawatia (2019), the findings indicate that earnings growth has a significant effect on asset quality of Indian banks, and they also indicate that the increasing competition-stability can lead to reduction in non-performing loans of private bank, bank specific indicators diversification and equity capital are important to determinants of asset quality, as well as shadow bank and corporate earnings have positive effect of non-performing loans in private bank.

Vighneswara Swamy (2010), the result shows that there is a positive relationship between the capital adequacy on profitability for commercial banks in India, and the industry specific and macroeconomic determinants of profitability for those commercial banks. That positive relationship between capital adequacy on profitability, and the impact of ownership style (private sector) to manage their profitability more efficiently than the public sector. This study contributes in identifying the determinants of quality of asset and profitability of banks. 
Vijaya Kittu Manda and Aruna Polistty (2018), The result shows that there is a negative relationship between volatility in asset quality on stock price. Also the study founds impact of some variables like asset quality bank size, knowledge bank non-performing loans, and monitoring risk management actually helping non-performing figures.

Petar Kasavica (2015) there is a positive impact of asset quality on profitability and maturity of portfolio in commercial bank.

Edward Bace (2016), there is negative correlation between profitability and level of liquid asset, and significant negative impact in profitability on non-performing loans. There is a strong positive effect of asset ratio with profit.

Mosao Fukui (2017), this research presented a model for relationship between asset quality and underlying moral hazard problems, and the relationship between asset prices and asset quality.

Nader Alber and Hatem Ramadan (2015), results show that there is a significant effect between the applying of Basel committee norms on asset quality of Egyptian banks, as well as a significant effect of (credit risk and operational risk) on asset quality, while there is no significant effect of applying Basel 2 on asset quality, although there is a significant effect of applying Basel 3 on asset quality.

Ahmed Aziz (2018), result shows that there is a significant relationship between liquidity and sustainable growth rate. Also there is a significant negative relationship between asset qualities although, there is a significant relationship between non-performing loan (as sub variable from asset quality) and sustainable growth rate, and there is a significant negative relationship between loans to finding rate as sub variable from asset quality on sustainable growth rate.

Ebrahim M. Al Matari (2020), this study aims to determine the bank profitability on the moderating role of bank liquidity, the results show that there is a significant relationship between the size of the bank and the management of asset, and there are significant relationships between the bank liquidity on capital adequacy and asset quality

Victor Oba (2015), the result shows that the regression model evidenced that capital adequacy positive relationship to asset quality, non-performing loans to total loans and to customers deposit has a positive relationship on return on investment.

Eyup Kadioglu et al., (2017), the result shows that there is a negative significant relationship between the non-performing loans and profitability investigated for the Turkish banking sector, also there is negative significant relationship between the ratio of return on asset / return on equity as the variable of profitability and the non-performing loans as variable of asset quality.

Tomasz Piskorski et al., (2013), the findings indicate that second liens misrepresentation loans performance is a negative significant coefficient for low- and no-documentation status consistent, also that Misreported Second Lien is positively significant with loans performance.

Ralph Kober \& et al (2012), this study sought to investigate the impact of the total quality management on financial performance on a small medium enterprise. The finding indicates that there is a negative relationship between total quality management and financial performance.

Jessica Wachter (2010), the results show there is a negative correlation with the dividend yield and the stock return, the optimal allocation as the function of horizon is substantial, and the market effect.

Mohamed Ariff (2019), the result shows that there are differences among different types of Malaysian banking sectors (covenantal bank conventional Islamic partnership - Islamic stand-alone) in terms of the efficiency, the Islamic bank subsidiaries perform best compared to other types of Malaysian banking and more stable regarding their financing income, while the stand-alone Islamic banks have a lower asset quality comparison with other types of Malaysian banks. The conventional bank and their Islamic subsidiaries tend to be more efficient and stable with better asset quality.

Richard Paul Vethamuthu (2019), the results show that the public sector banks in India have performed better than the private sector because the public sector focuses on enhancing net interest margin , profit per employee, return on asset and CRAR; all these are improving the asset quality.

Eston E. Chimkono et al (2016), the results show that non-performing loans are negatively related to the financial performance, the cost efficiency ratio has a significant relation with the financial performance, cash reserve requirements has a negative relation with the financial performance and average lending interest has a positive relationship with the financial performance. 
Dickson Pastory \& Marobhe Mutaju (2013), the conclusion of this study indicates that non- performing loans have a positive coefficient with capital adequacy.

Lie Jan Kao \& et al (2012), the result shows that the interest rate in banking sector is independent on the collateral asset and long term equilibrium interest rate.

Bert Schotens (2008), the finding of this study indicate that there is a negative association between the financial performance and social strength; also the study finding indicates that there is a weak negative relationship between the financial performance with stakeholder strengths and concerns. Besides, the finding shows the negative relationship between the financial returns and stakeholders concerns.

\section{Hypotheses}

$\mathrm{H}_{1}$ There is no significant relationship between the return on equity and asset quality

$\mathrm{H}_{2}$ There is no significant relationship between the liquidity and asset quality

$\mathrm{H}_{3}$ There is no significant relationship between the return on investment and asset quality

The null hypotheses in all of the instances is that there is no significant relationship between the financial performance and asset quality

\section{Research Objective}

1. The main objective of the research is to analyze the relationship between the profitability and liquidity on asset quality of insurance industry in Egypt

2. To investigate the impact of the financial performance of insurance industry on asset quality

\section{Methodology}

There is a need to estimate to relationship between the return on equity, return on investment and liquidity on asset quality by using panel data analysis methodology consisting of different insurance category, and data across a period from 1999 to 2019. The choice of this data depends on availability of published data on annual periodic reports from the Egyptian financial regulatory authority.

\subsection{Research Society and Sample}

Research society includes all insurance companies working under supervision of financial regulatory authority in Egypt through the period from 1999 - 2019 which are 39 companies by the end of 2019. The sample includes 19 companies which represents approximately $49 \%$ from the number of research society.

\subsection{Required Data}

Required data include ratio which concerning with research variable beside secondary data published by insurance companies through balance sheet and income statements. The model includes 4 variables as follows:

$$
\begin{aligned}
& 1 \text { - Asset Quality } Y \\
& 2 \text { - Return on equity } X_{1} \\
& 3 \text { - Liquidity } X_{2} \\
& 4 \text { - Return on investment } X_{3} \\
& \quad \text { Dependent variable }
\end{aligned}
$$

Asset quality

Independent variables

Return on equity

Liquidity

Return on investment
Earning Asset / Total Asset

$=($ Free Investment + Specialized Investment $) /$ Total Assets

$=($ Revenue - Expenditure $) /$ Equity

$=($ Cash + Deposit $+\mathrm{S} . \mathrm{T}$. Loans + Treasure Bills $) \quad /$ Total Assets

$=($ Revenue - expenditure $) /$ Total Investment 


\subsection{Statistical Tools}

To analyze the relationship between the independent variable and dependent variable using the Descriptive statistics

1- Mean 2-Median 3-Skewness 4-Kurtosis 5- standard deviation 6- Jarque-Bera 7-Probability

\subsection{Econometrics Methodology}

Panel data analysis (ARDL Model $-\mathrm{R}^{2}$ Coefficient $-\mathrm{F}$ test $-\mathrm{t}$-test - VIF - Jarque-Bera Test - Thiele's inequality coefficient $\mathrm{U}$ - Akaike information criteria for top 20 models - ARDL Co integrating and Long Run Form - ARDL Bounds Test - The Durbin-Watson test statistic - Breusch-Godfrey Serial Correlation LM Test Heteroskedasticity Test - Ramsey RESET Test

\section{Research Importance}

1-This research addresses the insurance industry in Egypt, especially the liquidity constraint which determines under supervision of the financial regularity authority in Egypt as mentioned in the introduction, profitability, and its impact on asset quality.

2- There is a lack of the literature review in insurance industry in Egypt in asset quality because most of literature review related to asset quality focused on the banking sector in Egypt.

\section{The Research Limitations}

1-The scope of this study was for 20 years from 1999-2019. During this period there has been an acquisition between MISR life insurance, Elsharq Company and NASG to QNB.

2- Some of the insurance companies published through study period like Sarwa insurance company (life and property)

\section{Testing Hypotheses}

8.1 Jarque-Bera Test, to Measure the Normality Distribution of All Research Variables

Table 1. Descriptive statistics for dependent and independent variables from 1999 to 2019

\begin{tabular}{ccccc}
\hline Constructs & $\mathrm{Y}_{1}$ & $\mathrm{X}_{1}$ & $\mathrm{X}_{2}$ & $\mathrm{X}_{3}$ \\
\hline Mean & 0.814718 & 0.138785 & 0.203807 & 0.041026 \\
Median & 0.824534 & 0.139345 & 0.093064 & 0.036967 \\
Maximum & 0.993822 & 0.474458 & 0.918528 & 0.134261 \\
Minimum & 0.548777 & -0.220321 & 0.000106 & -0.046607 \\
Std. Dev. & 0.097179 & 0.141172 & 0.221161 & 0.038342 \\
Skewness & -0.387299 & 0.082026 & 0.998195 & 0.355717 \\
Kurtosis & 2.775117 & 2.899317 & 2.961353 & 2.784185 \\
Jarque-Bera & 10.81580 & 0.615960 & 66.28503 & 9.188861 \\
Probability & $0.004481 * *$ & 0.734930 & $0.001 * * *$ & $0.010108 *$ \\
Observations & 399 & 399 & 399 & 399 \\
\hline
\end{tabular}

*** Significant at a level less than (0.001).

According to the above - shown table indicates that descriptive statistics of the study variables, the observed calculated descriptive statistics include the mean, medium, Maximum, minimum, standard deviation, skewness, kurtosis, Jarque-Bera and probability. The normality distributions of study variables in terms of x1(return on equity) by using the Jarque-Bera test at a significant level greater than (0.05). On the other hand the research variables in terms of y (asset quality), (liquidity) x2, and (return on investment) x3 are not normally distributed, whereas the significant of Jarque-Bera statistic is less than (0.05).

Since the Pearson skewness coefficient is less than or equal (1) or greater than or equal (-1) it can be concluded that the data are not significantly skewed. (Allan G.Bluman, 2012) 


\subsection{Group Unit Root Test}

Statistically, Unit root test tests a time series whether non stationary and possess for variables to be sure that the mean and variance are invariant over time, and the value of the covariance between two time periods depends only on the distance between the two time periods and not the actual time at which the covariance is computed of the return on equity, return on investment and liquidity on asset quality using the following statistical techniques: Augmented Dickey-Fuller (ADF), Philips-Perrron (PP), and Im, Pesaran and Shin W-stat (IPSW).

Table 2. Group unit root test for dependent and independent variables from 1999 to 2019

\begin{tabular}{|c|c|c|c|c|}
\hline Method & Statistic & Prob.** & $\begin{array}{l}\text { Cross- } \\
\text { sections }\end{array}$ & Obs \\
\hline \multicolumn{5}{|c|}{ Null: Unit root (assumes common unit root process) } \\
\hline Levin, Lin \& Chu $t^{*}$ & -9.14266 & $0.001 * * *$ & 4 & 1590 \\
\hline \multicolumn{5}{|c|}{ Null: Unit root (assumes individual unit root process) } \\
\hline Im, Pesaran and Shin W-stat & -11.7469 & $0.001 * * *$ & 4 & 1590 \\
\hline ADF - Fisher Chi-square & 149.569 & $0.001 * * *$ & 4 & 1590 \\
\hline PP - Fisher Chi-square & 209.456 & $0.001 * * *$ & 4 & 1592 \\
\hline
\end{tabular}

According to the above-shown table, it indicates that stationary of the time series of the y(asset quality), (return on equity) $\mathrm{X}_{1}$, (liquidity) $\mathrm{X}_{2}$, and (return on investment) $\mathrm{X}_{3}$, at level $1 \sim(0)$ based on the constant level, through to the following criteria; LLC, IPSW, PP, ADF, at a significant level less than (0.05).

\subsection{Co integrating Equation Model}

Statistically, Engle-Granger Co-integration test using to measure the existence of long-run equilibrium relationships among non-stationary time series variables in terms of $(\mathrm{Y})$ asset quality, $\left(\mathrm{X}_{1}\right)$ return on equity, $\left(\mathrm{X}_{2}\right)$ liquidity, and $\left(\mathrm{X}_{3}\right)$ return on investment, as follows:

Table 3. Co integrating Model for dependent and independent variables from 1999 to 2019

\begin{tabular}{ccccc}
\hline Dependent & tau-statistic & Prob.* & z-statistic & Prob.* \\
\hline $\mathrm{Y}$ & -5.731499 & $0.001 * * *$ & -65.81918 & $0.001 * * *$ \\
$\mathrm{X}_{1}$ & -8.498862 & $0.001 * * *$ & -120.6772 & $0.001 * * *$ \\
$\mathrm{X}_{2}$ & -8.313170 & $0.001 * * *$ & -115.3088 & $0.001 * * *$ \\
$\mathrm{X}_{3}$ & -9.548406 & $0.001 * * *$ & -148.6119 & $0.001 * * *$ \\
\hline
\end{tabular}

According to the above-shown table, it indicates that; there are long-term equilibrium relationships among (asset quality) as the dependent variable and variables (return on equity - liquidity - rerun on investment) as the independent variable s from 1999 to 2019, based on the both Tau-statistic, and z-statistic, at a significant level less than (0.05). 


\subsection{Pearson Correlation Matrix}

Table 4. Pearson correlation matrix to measure a significant linear relationship between the variables of the fixed panel data model

\begin{tabular}{|c|c|c|c|c|}
\hline Constructs & $\mathrm{Y}$ & $\mathrm{X}_{1}$ & $\mathrm{X}_{2}$ & $\mathrm{X}_{3}$ \\
\hline $\mathrm{Y}$ & 1 & & & \\
\hline $\mathrm{X}_{1}$ & -0.047738 & 1 & & \\
\hline $\mathrm{X}_{2}$ & -0.061102 & $-0.146772 * *$ & 1 & \\
\hline $\mathrm{X}_{3}$ & $-0.139261 * *$ & $0.647797 * * *$ & $-0.203725^{* * *}$ & 1 \\
\hline
\end{tabular}

$* * *$ Significant at a level less than (0.001).

** Significant at a level less than (0.01).

According to above-shown table, the study revealed that:

1-There is negatively significant linear relationship between return on investment (x3) with the asset quality (y) at a significant level less than (0.01).

2- There is no significant linear relationship between return on equity (x1) and liquidity (x2), with the asset quality (y) at a Significant level greater than (0.05).

8.5 ARDL (2, 0, 0, 4) Model

Table 5. ARDL (2, 0, 0, and 4) model to determine the effect of independent variables on Y

\begin{tabular}{|c|c|c|c|c|c|}
\hline Variable & Coefficient & Std. Error & t-Statistic & Prob. & VIF \\
\hline $\mathrm{Y}(-1)$ & 0.712359 & 0.050014 & 14.24309 & $0.001 * * *$ & 3.127154 \\
\hline$Y(-2)$ & 0.113143 & 0.050248 & 2.251689 & $0.0249 *$ & 3.158291 \\
\hline $\mathrm{X}_{1}$ & 0.006898 & 0.026381 & 0.261472 & 0.7939 & 1.822928 \\
\hline $\mathrm{X}_{2}$ & -0.013284 & 0.013230 & -1.004118 & 0.3160 & 1.088092 \\
\hline $\mathrm{X}_{3}$ & 0.069938 & 0.118388 & 0.590757 & 0.5550 & 2.731242 \\
\hline $\mathrm{X}_{3}(-1)$ & -0.257539 & 0.111533 & -2.309086 & $0.0215^{*}$ & 2.422647 \\
\hline $\mathrm{X}_{3}(-2)$ & 0.134792 & 0.113781 & 1.184667 & 0.2369 & 2.521679 \\
\hline $\mathrm{X}_{3}(-3)$ & 0.111790 & 0.111210 & 1.005213 & 0.3154 & 2.409705 \\
\hline$X_{3}(-4)$ & -0.290413 & 0.097309 & -2.984421 & $0.0030 * *$ & 1.840809 \\
\hline $\mathrm{C}$ & 0.152983 & 0.027282 & 5.607567 & $0.001 * * *$ & --- \\
\hline \multicolumn{6}{|c|}{ 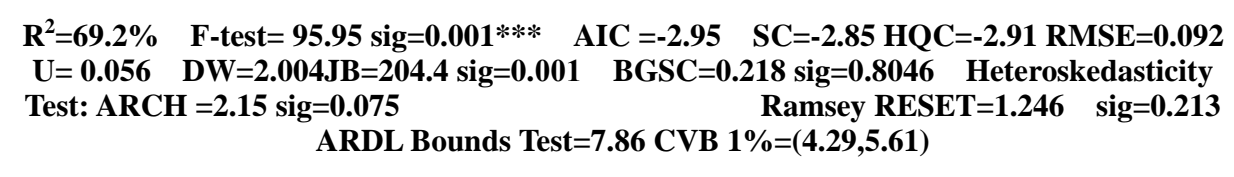 } \\
\hline \multicolumn{6}{|c|}{$\begin{array}{c}Y=0.712359270649 * Y(-1)+0.113143418872 * Y(-2)+0.00689789331513 * X 1- \\
0.0132841094292 * X 2+0.0699383487565 * X 3-0.257539031814 * X 3(-1)+ \\
0.134792033668 * X 3(-2)+0.111789938237 * X 3(-3)-0.290412501965 * X 3(-4)+0.152982958851\end{array}$} \\
\hline \multicolumn{6}{|c|}{ Cointeq $=Y-(0.0395 * X 1$} \\
\hline
\end{tabular}

According to above-shown table indicates that the panel estimation model using least squares, it can be concluded that:

\subsubsection{The Coefficient of Determination: $\mathrm{R}^{2}$}

The result shows that The $\mathrm{R}^{2}$ value is $69.2 \%$. that mean The Independent Variables ( Return on equity - liquidity

- Return on investment ) were accepted in the $\operatorname{ARDL}(2,0,0,4)$ model explain $(69 \%)$ from total variation of 
dependent variable (y) (asset quality), and the rest percent due to either the random error in the regression model or other Independent Variables excluded from regression model.

\subsubsection{F Test}

According the above-shown table indicates that, $\mathrm{F}$ test" is (95.95) at a significant level at less than $(0.001), \mathrm{t}$ the result that (return on equity, liquidity and return on investment) as independent variables were accepted in the model have been affected on the level of (asset on quality) $y$.

\subsection{3 t-test}

The most significant independent variables were accepted in the model are:

$\mathrm{Y}(-1), \mathrm{Y}(-2), \mathrm{X}_{3}(-1)$ and $\mathrm{X}_{3}(-4)$ significant level less than $(0.05)$.

\subsubsection{VIF}

Statistically, the VIF (The Variance Inflation Factors) is a calculation of the variance in a model, it computes the severity in an ordinary least square of regression model that used for analysis relationship between return on equity, return on investment and liquidity with the asset quality in this study, the problem appears with statistical technique when variance inflation factors exceed 10 , in this study as shown on above table the value of VIF less than 4 , therefore the model has not suffering from the multicollinearity problem.

\subsubsection{The Jarque-Bera Test}

However the significance value of the test statistic $(\leq 0.05)$, then we would reject the null hypothesis $(\mathrm{H} 0)$ : residuals are normally distributed. But Pearson skewness coefficient (-0.57) is greater than or equal (-1), it can be concluded that the data are not significantly skewed. (Allan G.Bluman, 2012)

\subsubsection{Thiele's Inequality Coefficient U}

U Thiele's inequality used to measure the accuracy of the estimates of the $\operatorname{ARDL}(2,0,0,4)$. The range from 0 to 1 , where zero indicates a perfect fit. Since a value reaches to zero $(0.056)$ indicating the goodness of fit of the panel model, at a percent of not less than (94\%).

\subsubsection{Akaike Information Criteria for Top 20 Models}

Based on the value of the AIC index, the best model for explaining the behavior of the dependent variable $y$ is the $\operatorname{ARDL}(2,0,0,4)$.

\subsubsection{ARDL Co integrating And Long Run Form}

The above-shown table indicates that, there is a long-term equilibrium relationships between asset quality (Y), as a dependent variable with (return on investment) $\mathrm{X}_{3}$ as independent variable, at a significant level less than (0.05), which indicates the relatively rapid changes in the asset quality $(\mathrm{Y})$, as a change of (10\%) lead to long-term changes of $(1.32 \%)$, in the independent variable in terms of return on investment $\left(\mathrm{X}_{3}\right)$.

\subsubsection{ARDL Bounds Test}

Whereas the calculated value of the ARDL Bounds (7.86) test is greater than the tabulated value at a significant level $(1 \%)$, indicates the reject of the null hypothesis that there are no long-term relationships between the variables of the ARDL $(2,0,0,4)$. This result shows that accepting the alternative hypothesis that there are long-term relationships between the independent variables and $\mathrm{y}$.

\subsubsection{The Durbin-Watson Test Statistic}

According to the above-shown table, it indicates that the value of The Durbin-Watson test statistic (2.004) compared with The Durbin-Watson statistic ranges in value from 0 to 4 . A value toward 4 indicates negative autocorrelation. Whenever the test statistic value (2.004) was greater than DU, the result shows not reject the null hypothesis.

Null hypothesis that the residuals from an Ordinary least-squares regression are not auto correlated against the alternative that the Residuals follow an AR1, positive first-order autocorrelation, process. A value near 2 indicates non-autocorrelation; a value toward 0 indicates positive autocorrelation; a value toward 4 indicates negative autocorrelation. Since the test statistic value (2.004) was greater than DU

\subsubsection{Breusch-Godfrey Serial Correlation LM Test}

The above-shown table indicates that the value of The Breusch-Godfrey serial correlation LM test is (.218) when the significance value of the BGSC test statistic $(\geq 0.05) ;(0.8046)$, the result shows that , would not reject the null hypothesis $(\mathrm{H} 0)$ : there is no serial correlation up to lag order $\mathrm{p} 2$. 


\subsubsection{Heteroskedasticity Test}

When using an Ordinary Least Squares (OLS), one of the important assumptions is the error term has a contrast variance (Homoskedasticity). If the error terms have not constant variance, it reflects the heteroskedastic. This might not be true even if the error term is assumed to be drawn from identical distributions.

By conducting the Heteroskedasticity Test: ARCH for the residuals values of the multiple regression model, it concluded that the level of significance for the tests: F-statistic, Obs * R-squared, is greater than $(0.05) ;(0.0746)$, which indicates the acceptance of the null hypothesis which provides for the Homoskedasticity of error term.

\subsubsection{Ramsey RESET Test}

According to the above-shown table the value of the Ramsey RESET TEST is $(=0.092)$ when the significance value of the t-statistic 'F-statistic 'Likelihood ratio test statistic $(\geq 0.05) ;(0.2134)$, the result shows that, would not reject the null hypothesis (H0): The functional form is correct, no omitted variables (extra terms are statistically not significant).

This test is method of testing whether there exist nonlinear significant relationship when build linear regression model and whether non-linear combinations of the fitted values, Along with that non-linear combinations of the explanatory variables have any power in explaining the response variable, Omitted Variables.

\section{Conclusion and Discussion}

This study attempts to analyze the impact of the financial performance on asset quality in insurance industry in Egypt as applied on a sample of 19 insurance companies over the period 1999- 2019 asset quality as measured by earning asset to total asset, while the financial performance measured by liquidity and profitability (return on equity - return on investment) results indicate that.

Pearson correlation matrix evidenced a significant negative linear relationship between the independent variable $\mathrm{X}_{3}$ in terms of (return on investment), and the dependent variable y ( asset quality) at a significant level less than (0.01). This result concurs with Eyup Kadioglu et al (2017). However panel data analysis result shows that The Independent Variables were accepted in the ARDL $(2,0,0,4)$ model explain $(69 \%)$ from total variation of dependent variable $(\mathrm{Y})$, and the rest percent due to either the random error in the regression model or other Independent Variables excluded from regression model

Also evidenced, there is no significant linear relationships between the independent variable of $\mathrm{X}_{1}$ return on equity, $\mathrm{X}$ liquidity 2, and dependent variable; $\mathrm{Y}$ asset quality at a Significant level greater than (0.05). This result concur with Edward Bace (2016) however the calculated value of the ARDL Bounds (7.86) test is greater than the tabulated value at a significant level $(1 \%)$, indicating the rejection of the null hypothesis that there are no long-term relationships between the variables of the ARDL $(2,0,0,4)$ and then accepting the alternative hypothesis that there are long-term relationships between the independent variables and $\mathrm{Y}$.

\section{References}

Abata, M. A. (2014). Asset Quality and Bank Performance: A Study of Commercial Banks in Nigeria. Research Journal of Finance and Accounting, 5(18).

Ahmad, A. P. P. (2018). Liquidity and Asset Quality on Sustainable Growth Rate of Banking Sector. International Journal of Science and Research, 7.

Allang, B. (2012). Elementary Statistics, a brief version. McGraw hill (6th ed.).

Bert, S. (2008). Stakeholder Relations and Financial Performance. Journal of Sustainable Development, 16(3). https://doi.org/10.1002/sd.364

David, B., \& Robert, K. (2019). Bank Asset Quality and Monetary Policy pass-through. Working Paper Series, No. 98, June.

Dickson, P., \& Marobhe, M. (2013). the Influence of Capital Adequacy on Asset Quality of Banks in Tanzania. International Journal of Economics and Finance, 5(2). https://doi.org/10.5539/ijef.v5n2p179

Ebrahim, M. A. M. (2020). The determinants of bank profitability of GCC: The role of the bank liquidity as moderating variable-Further analysis. International Journal of Finance \& Economic, 26(1).

Edward, B. (2016). Bank profitability: Liquidity, capital and asset quality. Journal of Risk Management in Financial Institutions, 9(4).

Eston, E. C. et al. (2016). Effect of Non-Performing Loans and Other Factors on Performance of Commercial Banks in Malawi. International Journal of Economics, Commerce and Management, IV(2). 
Eyup, K. et al. (2017). Effect of the Asset Quality on the Bank Profitability. International Journal of Economics and Finance, 9(7). https://doi.org/10.5539/ijef.v9n7p60

Festus, K. N. (2015). the Effect of Assets Quality of the Financial Performance of Commercial Banks in Kenya. University of Nairobi Research Archive.

Grace, W., \& Wang, Y. et al. (2013). Bank asset allocation: the effectiveness of market monitoring. Journal of Advances in Management research, 10(3). https://doi.org/10.1108/JAMR-07-2013-0046

Jessica, W. (2010). Asset Allocation. Working Paper 16255. Retrieved from http://www.nber.org/papers/w16255

Lie-Jane, K. et al. (2012). Why do banks default when asset quality is high? The International Journal of Business and Finance Research, 6(1).

Lucky, A. L., \& Nwosi, A. A. (2015). Asset Quality and Profitability of Commercial Banks: Evidence from Nigeria. Research Journal of Finance and Accounting, 6(18).

Masao, F. (2018). Asset Quality Cycles. Journal of Monetary Economics, 95(C), 97-108. https://doi.org/10.1016/j.jmoneco.2018.02.006

Mohamed, A., \& Fekri, A. S. (2019). Efficiency, Asset Quality and Stability of the Banking Sector in Malaysia. Malaysian Journal of Economic Studies, 56(1), 107-137. https://doi.org/10.22452/MJES.vol56no1.6

Nader, A., \& Hatem, R. (2015), the Impact of Applying Basel Committee Norms on Asset Quality of Egyptian Banks. International Business Research, SSRN Electronic Journal.

Nicholas, K. et al. (2019). Asset Quality as a Determinant of Commercial Banks Financial Performance in Kenya. International Journal of Economics, Commerce and Management, VII(2).

Petar, K. (2015). Impact of asset quality on bank profitability-Case Study. Industrija, 43(4). https://doi.org/10.5937/industrija43-9219

Rakesh, A. (2019). Asset quality determinants of Indian banks: Empirical evidence and policy issues. Journal of Public Affairs, 19(4). https://doi.org/10.1002/pa.1937

Ralph, K. et al (2012). The impact of total quality management adoption on small - medium enterprise, financial performance. Journal of Accounting and Finance, 53.

Raymond, A. E. (2016). Effect of Sustainability Environmental Cost Accounting on Financial Performance of Nigerian Corporate Organizations. International Journal of Scientific Research \& Management Studies, 4(8).

Richard, P. V. (2019). impact of asset quality on financial performance of banks in India comparative study of public private bank sector. International Research Journal of Arts and Science, 10(7).

Tajudeen, T. L. et al. (2018). Effect of Asset Quality on the Operational Efficiency of Deposit Money Banks in Nigeria. International Journal of Economics, Commerce and Management, VI(6).

Tomasz, P. et al (2015). Asset Quality Misrepresentation by Financial Intermediaries: Evidence from the RMBS Market. Journal of the Finance, LXX(6).

Tomasz, P. et al. (2013). Asset Quality Misrepresentation by Financial Intermediaries: Evidence from RMBS Market. the Journal of Finance, 70(6).

Victor, O. (2016). Impact of capital adequacy on asset quality of deposit money banks in Nigeria. Retrieved from https://ssrn.com/abstract=2775647

Vighneswara, S. (2010). Determinants of Bank Asset Quality and Profitability-An empirical Assessment. Applied Economics Quarterly, 63(1).

Vijaya, K. M., \& Aruna, P. (2018). Asset Quality \& Risk Management Practices-An Analysis on Yes Bank. Retrieved from https://ssrn.com/DOI=3510944

Vladimir, M. et al. (2016). Major aspects of asset quality review process in European Union and Serbia, Conference. International Scientific Conference at FACULTY OF ECONOMICS, UNIVERSITY OF NIŠ.

\section{Copyrights}

Copyright for this article is retained by the author(s), with first publication rights granted to the journal.

This is an open-access article distributed under the terms and conditions of the Creative Commons Attribution license (http://creativecommons.org/licenses/by/4.0/). 